\title{
On the International Convergence of Accounting Standards
}

\author{
Boka Moussa \\ Economics and Management School, Wuhan University \\ Wuhan 430072, China
}

Tel: 86-276-2770-904Ｅ-mail: bokamoussa@hotmail.com

\begin{abstract}
The international convergence of accounting standards has become a hot topic in the international accounting field. The convergence is an irreversible developing trend of accounting internationalization development that began many years ago.Accounting, as a world-wide accepted business language, should naturally move towards internationalization. This paper discusses the international convergence of accounting standards focusing on its development stages, necessity and analyzes the international status.
\end{abstract}

Keywords: Accounting Standards, International Convergence, Development stages, Necessity and Feasibility, International Status

\section{Introduction}

The international convergence of accounting standards is a global trend that began 30 years ago. The International Accounting Standards Committee (IASC) has contributed to the harmonization of accounting standards by issuing the International Accounting Standards (IAS).In 2001 the International Accounting Standards Committee (IASC) has been reconstituted as the International Accounting Standards Board (IASB). The International Accounting Standards Board made a commitment to achieve full convergence to a single set of high quality, understandable and enforceable global accounting standards, to promote the use of those standards, and to bring about convergence of national accounting standards and international standards.

\section{The Concept and Development Process of International Convergence of Accounting Standards}

\subsection{The definition of international convergence of accounting standards}

The Accounting standards differ from country to country for many raisons. These differences can cause problems for multinational corporations. In response to the problems, the International Accounting Standards Committee (IASC) was formed in 1973 to develop global accounting standards. In April 2001 the International Accounting Standards Committee (IASC) has been reconstituted as the International Accounting Standards Board (IASB). The International Accounting Standards Board IASB formally proposed a "Convergence" concept. Convergence nearly means the same, which is integration, that is, the world's different jurisdictions; the same economic transactions should be using the same accounting approach.

The international convergence of accounting standards includes the following definitions:

First: Convergence represents progress, and the direction for future development. Convergence furthers harmonization and embodies the requirements of integrating international economies. Any organization that hopes to remain in the international market cannot afford to disregard the trend of international convergence. However, convergence requires concerted and maximum effort to be realized.

Second: Convergence does not equal identicalness. Countries differ in economic environments, legal systems, cultural philosophies, regulatory structures, users of accounting information and quality of accountants. Without paying due attention to national situations, accounting/audit development status or environmental features, we will be unable to achieve true convergence.

Third: Convergence is a process. Due to different national characteristics, countries in the world need to continuously and actively carry out voluntary cooperation, study new situations, address new issues and innovate new mechanisms to create a structure which meets such requirements as international efficiency, equitability, sovereignty, and development of global diversity.

Fourth: Convergence means interaction. Convergence does not mean one-way movement. It means interaction between different countries, between individual countries and IASB, and between IASB and regional professional accounting bodies. They need to communicate with each other, to draw upon from each other, and to obtain mutual recognition from each other. International convergence in the context of a world of diversities is an objective law. By complying with it, we can make better progress. Otherwise, effectiveness and efficiency may be compromised. 
From the above concepts of accounting standards and convergence, we can conclude that the convergence of national accounting standards is necessary and possible, however in the process there are inevitably some differences.

\subsection{The development process of international convergence of accounting standards}

The rapid globalization of capital markets, however, has resulted in further acceleration in the global convergence of accounting standards, as national accounting standards are being converged with one another.

In recent years, the use of International Financial Reporting Standards (IFRSs) has been expanding. While the consistency in their application remains yet to be confirmed, IFRSs is used, mandatorily or optionally, in many countries.

From some knowledge about the concept of the international convergence of accounting standards, we can illustrate roughly three stages which are: International Comparison, International Harmonization and International Convergence.

(1) International Comparison, along with the appearance of the international trade and the multinational capital flows, the accounting international comparison has emerged. The accounting international Comparison mainly refers to a comparaison among different countries accounting standards. The accounting standards' international comparison can reveal similarities and differences among different national accounting systems, and provide conditions to the international harmonization of accounting standards.

(2) International Harmonization, Generally agreed that the international dimension of economic development, promote international harmonization of accounting.

The Economic Globalization plays an important role in promoting the international harmonization of accounting. The level of international harmonization of accounting standards has gradually improved, so that international convergence of accounting standards is possible.

(3) International Convergence, the global convergence of accounting standards is driven by the economic globalization, the countries national accounting standards constantly continued with the international comparison and harmonization to establish a global common accounting standards target development such a dynamic process.

\section{The Necessity of International Convergence of Accounting Standards}

Accounting is a product of the economic environment, specific historical periods as well as directly restricts economic background determines the main features of this period, accounting and the basic trend. Today's era of international convergence of accounting standards is also true background. After 1990's the world trend is clearly accelerating economic globalization, international trade, international investment and multinational companies have shown good development trend, the growing capital market, cross-border mergers have become increasingly frequent and intensified, capital flows are also increasingly rapidly. In this case, the request for the international convergence of accounting standards becomes urgent.

(1) The trend of economic globalization required international convergence of accounting standards requirements

In the late of the 20th century, the world economic globalization trend is clearly accelerating, so in the context of any country to get rid of world trade and capital markets to seek self-development are inconceivable. And accounting as the national language of business, in economic globalization plays an increasingly important role, accounting information quality directly influences the level of market transactions, the quality and the effective allocation of global resources. Therefore, to promote convergence of accounting standards for the provision of comparable and transparent financial information is essential.

(2) International organizations to promote international convergence of accounting standards

With the increasing globalization of the world economy, international organizations are playing an increasingly important role in the international convergence of accounting standards. World Trade Organization, the SFC national organizations and the World Bank have expressed the hope that States Securities and Futures Commission, banks, enterprises, the adoption of international accounting standards.

(3) The rapid development of multinational companies required for convergence of accounting standards

The rapid development of economic globalization results in the emergence of multinational companies sprang up like mushrooms out of the influence on the world economy growing. Multinational operators in order to maximize profitability, reduce risk and certainly hope to have able to eliminate the country-specific differences 
for all countries recognized by the accounting standards, in order to facilitate their economic activities.

(4) International investment activities to promote international convergence of accounting standards

In addition to multinational corporations, other forms of direct or indirect cross-border investment has also gained considerable development, such as the investors through venture funds, insurance funds and other forms of foreign companies to buy stocks, such as through joint ventures or co-operative approach to foreign investment. For investors, if they can quickly access and understand the true object of the vote in reliable, detailed and unambiguous financial information to assess the size of the investment risk, then he would quickly make the appropriate investment decisions. On the contrary, such as the lack of such necessary financial information, investors will hesitate, hesitate. For enterprises to provide financial information comparable at the international level to reduce due to international differences in accounting standards and practices to bring foreign investors to read and use financial reporting problems, we must be the harmonization of national accounting standards, to promote its international convergence.

\section{The International Status of International Convergence of Accounting Standards}

International Accounting Standards Board (IASB) chairman David • Teddy said by early 2006 more than 100 countries and regions allow or require the adoption of international financial reporting standards. The International Financial Reporting Standards will be the world's major capital markets to be unified. At present, the international standards of national accounting standards convergence process has accordingly developed a wide range of protection mechanism.

Mainly manifested in the the following:

(1) International Accounting Standards Board (IASB) convergence in accordance with international requirements, to conduct a comprehensive structural reorganization, created a convergence of international standards to promote the development of new mechanisms. 2001 IASC standard-setting bodies and the accounting profession "decoupling", reorganized as a separate legal entity (IASB). IASB standard-setting bodies to cooperate with national strategies, with the United States, Britain, Canada, Australia, Germany, France, the G-7 standard-setting bodies to establish a strategic partnership, through the Advisory Committee and other channels with the developing countries have established communication and consultation mechanism. IASB accounting standards have been raised from various countries; "coordinator" has become a "global accounting standards," makers.

(2) International Accounting Standards to be recognized a number of international organizations, forming IASB cooperation with international organizations to promote the practice of international norms. IASB seize the opportunity to adjust its position and policies to continuously improve the authority's strategy of international accounting standards by international organizations and many national leaders of the "substantial authority" to support and cooperate in the promotion of international accounting standards of the practical actions, such as the Securities Commission International Organization (IOSCO), to develop the core standards system, IOSCO to the world, including the United States recommended the use of all major capital markets, and get the Group of Seven support. IMF, World Bank and other international development banks also have a loan the state and enterprises in accordance with international accounting standards to provide financial information. To more effectively promote trade in goods and promote trade in services, WT0 also strongly supported the promotion of international accounting standards.

(3) Many countries have embarked on a path of international convergence of accounting standards in many countries of the European Union have embarked on a path of international convergence of accounting standards, most of the major developed countries to consider the development and convergence of International Financial Reporting Standards calendar. October 29, 2002, the U.S. FASB and IASB reached a formal agreement, expressing the mutual convergence of positions. July 3, 2002, the Australian Financial Reporting Council (AFRC) officially released the international convergence of accounting standards on the announcement.

\section{Conclusion}

The accounting internationalization is the inherent requirements of the economic and capital markets globalization. The international convergence of national accounting standards has become a global economic stage of development inevitable trend. International accounting convergence objectives are: to find appropriate ways to work together to build a global system of high-quality accounting standards. Convergence is a gradual and interactive process that requires countries or regions to make unremitting efforts towards the process of implementation problems and difficulties should have a full understanding and preparation. High-quality globally accepted accounting standards system, not only for maintaining and promoting global economic 
stability and development of beneficial, but also for the healthy development of each country's economy and integration into the world economic system is also very important.

\section{References}

Dai, Huayue. (2007). On international convergence of accounting standard. Vol.2

Li, Yingfang. (2008). On international convergence of accounting standards. Economic \& Trade Update, Vol.6

Liu, Jinxing. (2009). Convergence of international accounting standards: Process and Status. Accounting Learning, June.

Zhu, Hailin, \& Liugang. (2003). Report on the international convergence of accounting standards. Certified Public Accountant, Vol.4

Zhu, Xingwen. (2009). Chinese view on international convergence of accounting. Contemporary Finance \& Economics, Vol.2. 